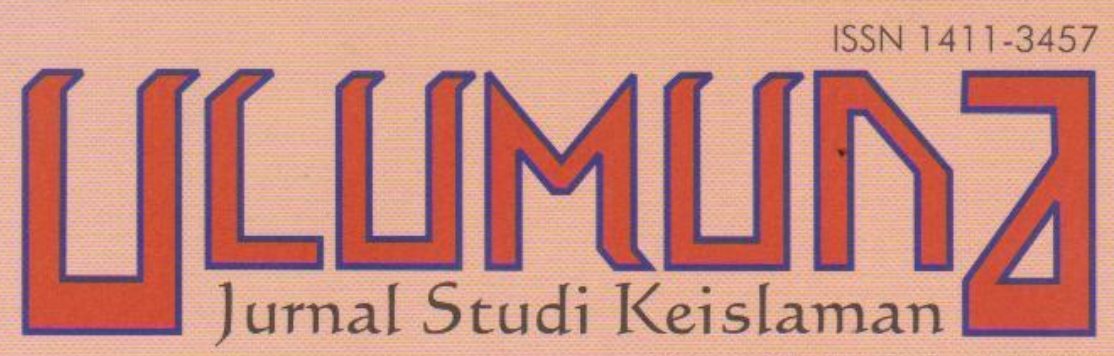

Volume XII• Nomor 1• Juni 2008

STUDI ANALITIS DIMENSI SACIFACT PENDIDIKAN ISLAM PADA MASA KEJAYAANNYA (750-1258 M) Abdul Fattah

AKTUALISASI MANUSIA VERSI AL-QUR'AN: ANTARA IDEALITAS DAN REALITAS PENDIDIKAN ISLAM Ismail Thoib

PENDIDIKAN ISLAM DAN PENCERAHAN SPIRITUALITAS: IKHTIAR MENJAWAB TANTANGAN POSMODERNISME Suparta

LESSON STUDY DALAM PEMBELAJARAN AGAMA ISLAM DI SEKOLAH UMUM Ahmad Munjin dan Khoirul Adib

STUDI PERUBAHAN KELEMBAGAAN DAN METODOLOGI PADA MADRASAH MODEL Taufik Churahman dan Musfigon POSISI PEREMPUAÑ
PERSPEKTIF ULAMA KLASIK
Baehaqi 


\section{PEDOMAN TRANSLITERASI}

\begin{tabular}{|c|c|c|c|}
\hline Arab & Latin & Arab & Latin \\
\hline 1 & $=$ & ف & $=\mathbf{f}$ \\
\hline ب & $=$ & ق & $=\mathrm{q}$ \\
\hline$\dot{H}$ & ts & ك & $=\mathbf{k}$ \\
\hline ج & $=$ & $J$ & $=1$ \\
\hline$\tau$ & $=$ & b & $=\mathrm{m}$ \\
\hline$\dot{\tau}$ & $=\quad \mathrm{kh}$ & $\dot{0}$ & $=\mathbf{n}$ \\
\hline$د$ & $=$ & و - - - 1 & $=\mathbf{w}$ \\
\hline$\dot{j}$ & $\mathrm{dz}$ & • & $=h$ \\
\hline$\jmath$ & $=$ & $\&$ & $=$, \\
\hline j & $=$ & ي & $=y$ \\
\hline س س & $=$ & & \\
\hline ش & $=$ & \multirow{2}{*}{\multicolumn{2}{|c|}{$\begin{array}{l}\text { Untuk Madd } \\
\text { dan Diftong }\end{array}$}} \\
\hline ص & sh & & \\
\hline ض & dl & i & $=$ â (a panjang) \\
\hline b & th & إين & $=\hat{\mathbf{1}}(\mathbf{i}$ panjang) \\
\hline ظ & $\mathrm{zh}$ & أوْ & $=\quad \hat{\mathbf{u}}$ (u panjang) \\
\hline$\varepsilon$ & $=$ & 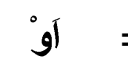 & $=a w$ \\
\hline$\dot{\varepsilon}$ & $=g h$ & آين & $=$ ay \\
\hline
\end{tabular}




\section{ISI}

TRANSLITERASI

ANTARAN

UTAMA

Abdul Fattah

Studi Analitis Dimensi Sacifact Pendidikan Islam pada Masa Kejayaannya $(750-1258 \mathrm{M}) \bullet 1-28$

Ismail Thoib

Aktualisasi Manusia Versi Al-Qur'an:

Antara Idealitas dan Realitas

Pendidikan Islam • 29-46

Suparta

Pendidikan Islam dan Pencerahan

Spiritualitas: Ikhtiar Menjawab Tantangan

Posmodernisme • 47-66

Ahmad Munjin Nasih Lesson Study dalam Pembelajaran

dan Khoirul Adib Pendidikan Agama Islam

di Sekolah Umum • 67-88

Taufik Churahman Dinamika Pendidikan Islam: Studi

dan Musfiqon

Perubahan Kelembagaan dan Metodologi

pada Madrasah Model • 89-106

LEPAS

Mutawalli Pembaruan Hukum Islam:

Menimbang Tawaran Pemikiran

'Abd al-Lâh al-Na'îm • 107-128

Baehaqi Posisi Perempuan

Perspektif Ulama Klasik • 129-142

Ahmad Sulhan Islam Kontemporer: Antara Reformasi

dan Revolusi Peradaban • 143-156

Ahmad Choirul Rofiq Menilai Kompetensi al-Mâturîdî di Bidang

Tafsir al-Qur'an • 157-182

ULAS BUKU

Yayuk Fauziyah Menyingkap Kuasa Maskulinitas di Balik

Tabir Feminitas Wanita Jawa • 183-200

INDEKS 


\title{
LESSON STUDY DALAM PEMBELAJARAN PENDIDIKAN AGAMA ISLAM DI SEKOLAH UMUM
}

\author{
Ahmad Munjin Nasih \\ Khoirul Adib*
}

\begin{abstract}
Innovation of education always becomes hot topic to be discussed from time to time because the fact shows that conventional learning methods are still used in educational institutions. Teachers are always viewed as experts who totally hold the power to transfer knowledge and give doctrines to students. The time has come to change this condition. Lesson study (LS) may be one of ways to shift such old paradigm. In that way, teachers should open their classes to be observed by anyone involved in learning process and activities. Therefore, teachers will know weaknesses and strengths of their methods.

This article examines $L S$ as an alternative model of improving professionalism of PAI teahers. The model can be aplied based on the principles of colleagues and mutual learning in order to establish a learning community through a gradual and cyclics steps.
\end{abstract}

Keywords: Lesson Study, PAI, Sekolah Umum.

BANYAK kalangan menilai bahwa mutu pendidikan di Indonesia masih tergolong memprihatinkan. Hal ini sudah barang tentu menjadi tantangan bagi setiap elemen yang terlibat dalam pendidikan untuk meningkatkan mutu pendidikan itu sendiri. Sebagaimana diyakini bahwa mutu pendidikan sangat berbanding lurus dengan mutu (kualitas) para pendidiknya.

*Kedua penulis adalah dosen Jurusan Sastra Arab dan Tim Dosen PAI Universitas Negeri Malang. email: munjin_nasih1@yahoo.com 
Artinya, kualitas suatu pendidikan sangat dipengaruhi oleh seberapa tinggi tingkat profesionalitas para pendidiknya.

UU Nomor 14 Tahun 2005 tentang Guru dan Dosen dan PP Nomor 19/2005 telah merumuskan parameter bagaimana seorang guru bisa dikategorikan sebagai pendidik yang profesional. Merujuk pada UU dan PP tersebut, seorang pendidik dikatakan memiliki keprofesionalan jika mereka setidaknya memiliki empat kompetensi, yakni kompetensi pedagogik, kompetensi kepribadian, kompetensi profesional, dan kompetensi sosial. Namun demikian untuk menjadi pendidik profesional diperlukan usaha-usaha yang sistemik dan konsisten serta berkesinambungan dari pendidik itu sendiri dan pihak pengambil kebijakan.

Selain aspek profesionalitas guru, hal penting lainnya yang harus dilakukan dalam rangka meningkatkan mutu pendidikan adalah pembaruan dalam aspek efektivitas metode pembelajaran. ${ }^{1}$ Pembaruan efektivitas metode pembelajaran dimaksudkan bahwa harus ada upaya terobosan untuk mencari strategi dan metode pembelajaran yang efektif oleh guru di dalam kelas.

Pada saat ini, kita masih sering melihat model pembelajaran yang konvensional berlangsung di berbagai lembaga pendidikan. Sebuah sistem di mana guru selalu ditempatkan sebagai pihak serba bisa yang berkuasa sepenuhnya untuk mentransfer berbagai ilmu pengetahuan dan memberikan doktrin-doktrin. Sementara itu, siswa sebagai objek penerima ilmu pengetahuan harus melaksanakan segala doktrin yang disampaikan oleh guru tanpa boleh membantah. Ketika mengajar di kelas, sang guru seolaholah mempunyai hak penuh untuk berbicara, sementara siswa harus diam mendengarkan dengan baik tanpa diberi kesempatan untuk mengembangkan kemampuan kritisnya.

${ }^{1}$ Nurhadi, dkk. Pembelajaran Kontekstual dan Penerapannya dalam KBK. (Malang: UM Press, 2004), 1. 
Kondisi guru yang demikian dominan setidaknya berakibat kepada lahirnya superioritas guru dan minimnya input dari pihak lain demi perbaikan kinerja guru. Hal itu bisa difahami, sebab semakin superior seorang guru, maka ada "ketakutan" dari pihak lain untuk memberikan masukan kepada gurunya. Akibat selanjutnya, mereka tidak pernah mengetahui apakah pembelajaran yang dilakukan sudah benar dan baik, demikian juga apakah metode yang mereka lakukan telah efektif bisa diterima oleh siswa atau belum.

Fenomena di atas, tidak bisa dipungkiri terjadi juga pada guru-guru Pendidikan Agama Islam (selanjutnya disebut PAI) yang mengajar di sekolah umum (non agama). Melihat kenyataan itu, perlu kiranya kita mencari solusi pemecahan yang tepat untuk mengatasi permasalahan tersebut. Pertanyaannya sekarang adalah sistem pengajaran yang bagaimanakah yang dapat dijadikan alternatif untuk meningkatkan kualitas pendidikan kita? Strategi dan metode pengajaran yang bagaimanakah yang dapat dijadikan alternatif terbaik untuk anak didik kita?

Dalam konteks inilah Lesson Study (selanjutnya disingkat LS) diyakini mampu meningkatkan profesionalisme pendidik, sebab LS merupakan model pembinaan profesi pendidik secara kolaboratif dan berkesinambungan berlandaskan prinsip-prinsip kolegalitas dan mutual learning untuk membangun komunitas belajar. Dengan kata lain, $L S$ diyakini mampu menjadi lokomotif penggerak gerbong pendidikan. Konon, Jepang sebagai negeri asal LS (Jugyokenkyu), mampu menjadi kiblatnya reformasi pendidikan bagi banyak negara maju, salah satunya karena menjadikan $L S$ sebagai budaya dan basis pembelajaran yang terus-menerus dikembangkan.

\section{Kedudukan PAI di Sekolah Umum}

Pendidikan nasional dari waktu ke waktu pada dasarnya adalah pendidikan yang diarahkan untuk membentuk watak, karakter, dan kepribadian bangsa yang berlandaskan pada ajaran 
moral, di samping sudah barang tentu untuk memberikan bekal pengetahuan, keterampilan dan penguasaan teknologi pada anak didik. $^{2}$ Untuk itulah perhatian terhadap pendidikan agama sebagai media pembentukan kepribadian, watak, dan karakter bangsa pada semua jenjang pendidikan, menjadi sesuatu yang sangat penting.

Bertolak dari pemikiran di atas, Pusat Kurikulum (Puskur) Depdiknas telah merancang kurikulum pendidikan agama untuk SD sampai SMU sedemikian rupa sehingga bisa menjadi dasar pembentukan karakter bangsa. Pengertian PAI sebagaimana dirumuskan oleh Puskur adalah upaya sadar dan terencana dalam menyiapkan peserta didik untuk mengenal, memahami, menghayati hingga mengimani, bertakwa, dan berakhlak mulia dalam mengamalkan ajaran agama Islam dari sumber utamanya kitab suci al-Quran dan hadis, melalui kegiatan bimbingan, pengajaran, latihan, serta penggunaan pengalaman. Dibarengi tuntunan untuk menghormati penganut agama lain dalam hubungannya dengan kerukunan antarummat beragama dalam masyarakat hingga terwujud kesatuan dan persatuan bangsa. ${ }^{3}$

Mata pelajaran PAI secara keseluruhan terbagi dalam empat cakupan: al-Quran dan hadis, keimanan, akhlak, dan fiqh/ibadah. Cakupan tersebut setidaknya menggambarkan bahwa ruang lingkup PAI diharapkan dapat mewujudan keserasian, keselarasan, dan keseimbangan hubungan manusia dengan Allah swt., diri sendiri, sesama manusia, makhluk lainnya

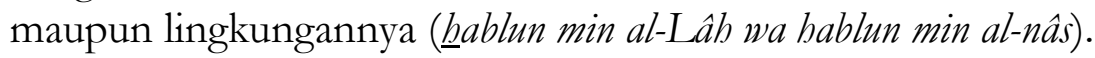

Selain itu, PAI menurut Puskur berfungsi untuk: (1) penanaman nilai ajaran Islam sebagai pedoman mencapai

${ }^{2}$ Lilik Nur Khalidah, "Model Internalisasi Nilai-nilai Moral Melalui Pendekatan Pemecahan Masalah dengan Kemandirian Aktif Mahasiswa Pada Mata Kuliah Pengembangan Kepribadian Pendidikan Agama Islam", Jurnal IPS dan Pengajarannya (2004), 68.

3Pusat Kurikulum Depdiknas, Standar Kompentensi Mata Pelajaran Agama Islam Sekolah Dasar dan Madrasah Ibtidaiyyah (Jakarta: Depdiknas, 2004), 4. 
kebahagiaan hidup di dunia dan akhirat; (2) pengembangan keimanan dan ketakwaan kepada Allah swt. serta akhlak mulia peserta didik seoptimal mungkin, yang telah ditanamkan lebih dahulu dalam lingkungan keluarga; (3) penyesuaian mental peserta didik terhadap lingkungan fisik dan sosial melalui PAI; (4) perbaikan kesalahan-kesalahan, kelemahan-kelemahan peserta didik dalam keyakinan, pengamalan ajaran agama Islam dalam kehidupan sehari-hari; (5) pencegahan peserta didik dari hal-hal negatif budaya asing yang akan dihadapinya sehari-hari; (6) pengajaran tentang ilmu pengetahuan keagamaan secara umum (alam nyata dan non nyata), sistem dan fungsionalnya; (7) penyaluran siswa untuk mendalami pendidikan agama ke lembaga pendidikan yang lebih tinggi. ${ }^{4}$

Lebih lanjut Puskur menjelaskan bahwa tujuan PAI adalah untuk menumbuhkan dan meningkatkan keimanan, melalui pemberian dan pemupukan pengetahuan, penghayatan, pengamalan serta pengalaman peserta didik tentang agama Islam sehingga menjadi manusia muslim yang terus berkembang dalam hal keimanan, ketakwaannya kepada Allah swt. serta berakhlak mulia dalam kehidupan pribadi, bermasyarakat, berbangsa dan bernegara, serta untuk dapat melanjutkan pada jenjang pendidikan yang lebih tinggi.

\section{Sekilas tentang Lesson Study}

Inovasi pendidikan menjadi topik yang selalu hangat dibicarakan dari masa ke masa. Isu ini juga selalu muncul tatkala orang membicarakan tentang hal-hal yang berkaitan dengan pendidikan. Inovasi pendidikan, secara umum, dapat dibedakan dalam dua buah model inovasi. Pertama, top-down model, yakni inovasi pendidikan yang diciptakan oleh pihak tertentu sebagai pimpinan/atasan yang diterapkan kepada bawahan; seperti halnya inovasi pendidikan yang dilakukan oleh Depdiknas

${ }^{4} I b i d, 6$. 
selama ini. Kedua, bottom-up model, yaitu model inovasi yang bersumber dan hasil ciptaan dari bawah dan dilaksanakan sebagai upaya untuk meningkatkan penyelenggaraan dan mutu pendidikan.

Selama ini pemerintah sesungguhnya selalu melakukan usaha peningkatan mutu guru melalui pelatihan dan tidak sedikit dana yang dialokasikan untuk keperluan pelatihan-pelatihan tersebut. Sayangnya usaha dari pemerintah itu kurang memberikan dampak yang signifikan terhadap peningkatan mutu guru. Setidaknya ada dua hal yang selama ini disinyalir menyebabkan pelatihan-pelatihan guru (dosen) belum berdampak pada peningkatan mutu pendidikan. Pertama, pelatihan tidak berbasis pada permasalahan nyata di dalam kelas. Materi pelatihan yang sama disampaikan kepada semua guru tanpa mengenal daerah asal. Padahal kondisi sekolah di suatu daerah belum tentu sama dengan sekolah di daerah lain. Kadang-kadang pelatih menggunakan sumber dari literartutr asing tanpa melakukan ujicoba terlebih dahulu maupun penyesuaian-penyesuaian untuk kondisi sosio-kultural Indonesia.

Kedua, hasil pelatihan hanya menjadi pengetahuan saja, tidak ditrerapkan pada pembelajaran di kelas ataupun kalau diterapkan mungkin hanya sekali, dua kali, dan selanjutnya kembali ke asalnya seperti dulu lagi. Hal itu bisa disebabkan karena content yang disampaikan dalam pelatihan itu sulit atau tidak aplikatif untuk bisa diimplementasikan dalam kelas. Hal lain, bisa jadi disebabkan tidak adanya kegiatan monitoring pasca pelatihan, apalagi kalau pihak sekolah (terutama pimpinan) tidak pernah menanyakan hasil pelatihan dan tidak tersedianya forum sharing pengalaman di antara guru-guru.

Untuk mengatasi kelemahan pelatihan-pelatihan konvensional yang selama ini dirasa kurang bernilai guna dan kurang menekankan pada pasca pelatihan maka menurut hemat penulis, LS menawarkan model (pola) in-service trainning yang 
lebih memfokuskan pada upaya pemberdayaan guru sesuai kapasitas serta permasalahan yang dihadapi masing-masing.

$L S$ adalah suatu model (pola) pembinaan profesi pendidik melalui pengkajian (studi) pembelajaran secara kolaboratif dan berkelanjutan berlandaskan prinsip-prinsip kolegalitas dan mutual learning untuk membangun komunitas belajar. ${ }^{5}$ Dengan demikian, $L S$ bukan sebuah metode atau strategi pembelajaran tetapi serangkaian kegiatan pembelajaran yang dapat diterapkan di dalamnya berbagai motode atau strategi pembelajaran yang dianggap efektif dan sesuai dengan situasi, kondisi, dan permasalahana faktual yang dihadapi guru di kelas nyata.

LS dilaksanakan dalam tiga tahapan yaitu: plan (merencanakan), do (melaksanakan), dan see (merefleksi) yang berkelanjutan. Dengan kata lain, $L S$ merupakan suatu cara peningkatan mutu pendidikan yang tak pernah berakhir (continous improvement), alias inovasi yang tiada henti. Peningkatan mutu pendidikan melalui $L S$ dimulai dari tahap perencanaan (plan) yang bertujuan untuk merancang pembelajaran yang dapat membelajarkan siswa dan berpusat pada siswa, bagaimana supaya siswa berpartisipasi aktif dalam proses pembelajaran. Perencanaan yang baik tidak dilakukan sendirian tetapi dilakukan bersama, beberapa guru dapat berkolaborasi atau guru-guru dan dosen dapat pula berkolaborasi untuk memperkaya ide-ide dan wawasan.

Perencanaan diawali dari analisis permasalahan yang dihadapi dalam pembelajaran. Permasalahan dapat berupa materi bidang studi, bagaimana menjelaskan suatu konsep. Permasalahan dapat juga berupa pedagogi tentang metode pembelajaran yang tepat agar pembelajaran lebih efektif dan efisien, atau tentang ketersediaan fasilitas pembelajaran yang kurang memadai. Selanjutnya guru secara bersama-sama mencari solusi terhadap

${ }^{5}$ Catherine Lewis. Does Lesson Study Have a Future in the United States?. http://www.sowi-online.de/journal/2004-1/lesson lewis.htm, diakses pada 2 Januari 2009. 
permasalahan yang dihadapi yang dituangkan dalam rancangan pembelajaran (lesson plan), teaching materials berupa media pembelajaran dan lembar kerja siswa serta metode evaluasi.

Teaching materials yang telah dirancang perlu diujicoba sebelum diterapkan di dalam kelas. Pertemuan-pertemuan yang sering dilakukan dalam workshop antara guru-guru dan dosendosen dalam rangka perencanaan pembelajaran mendorong terbentuknya kolegalitas antara guru dengan guru, dosen dengan guru, dosen dengan dosen, sehingga dosen tidak merasa lebih tinggi atau sebaliknya guru tidak merasa lebih rendah. Mereka sharing pengalaman dan saling belajar sehingga melalui kegiatankegiatan pertemuan dalam rangka $L S$ ini terbentuk mutual learning (saling belajar).

Langkah selanjutnya dalam $L S$ setelah perencanaan adalah pelaksanaan (do) pembelajaran untuk menerapkan rancangan pembelajaran yang telah dirumuskan dalam perencanaan. Dalam perencanaan telah disepakati siapa guru yang akan mengimplementasikan pembelajaran dan sekolah yang menjadi tuan rumah. Langkah ini bertujuan untuk mengujicoba efektivitas model pembelajaran yang telah dirancang. Guru-guru lain dari sekolah yang bersangkutan atau dari sekolah lain bertindak sebagai observer pembelajaran. Observer juga bisa datang dari para dosen, mahasiswa, dinas pendidikan, dewan sekolah, komite sekolah maupun pihak-pihak lain yang berkenan dan peduli dengan pembelajaran tersebut. Termasuk kepala sekolah juga terlibat dalam pengamantan pembelajaran sekaligus sebagai pemandu kegiatan ini.

Sebelum pembelajaran dimulai sebaiknya dilakukan briefing kepada para pengamat untuk menginformasikan kegiatan pembelajaran yang direncanakan oleh seorang guru sekaligus mengingatkan bahwa selama pembelajaran berlangsung pengamat tidak mengganggu kegiatan pembelajaran tetapi mengamati aktivitas siswa selama pembelajaran. Fokus pengamatan ditujukan pada interaksi siswa-siswa, siswa-sumber 
belajar/bahan-ajar, siswa-guru dan siswa-lingkungan. Lembar observasi pembelajaran perlu dimiliki oleh para pengamat sebelum pembelajaran dimulai. Para pengamat dipersilahkan mengambil tempat di ruang kelas yang memungkinkan dapat mengamati aktivitas siswa. Biasanya para pengamat berdiri di sisi kiri dan kanan di dalam ruang kelas agar aktivitas siswa dapat teramati dengan baik. Selama pembelajaran berlangsung, para pengamat tidak boleh berbicara dengan sesama pengamat dan tidak mengganggu aktivitas serta konsentrasi siswa.

Di luar kegiatan di atas, para pengamat dapat pula melakukan perekaman kegiatan pembelajaran melalaui video camera atau foto digital untuk keperluan dokumentasi dan bahan studi lebih lanjut. Keberadaan para pengamat di dalam ruang kelas disamping mengumpulkan informasi juga dimaksudkan untuk belajar dari pembelajaran yang sedang berlangsung dan bukan untuk mengevaluasi guru, apalagi "menghakiminya".

Langkah selanjutnya dalam kegiatan $L S$ adalah refleksi (see). Setelah selesai pembelajaran, langsung dilakukan diskusi antara guru dan para pengamat yang dipandu oleh kepala sekolah atau personel yang ditunjuk untuk membahas pembelajaran. Guru mengawali diskusi dengan menyampaikan kesan-kesan dalam melaksanakan pembelajaran, selanjutnya para pengamat diminta menyampaikan komentar dan lesson lent dari pembelajaran terutama berkenaan dengan aktivitas siswa. Jika pengamat hendak memberi kritik atau saran kepada guru, tentunya itu semua disampaikan secara bijak demi perbaikan pembelajaran. Di pihak lain, guru pun harus dapat menimbang dan menerima masukan dari pengamat untuk perbaikan pembelajaran berikutnya.

Berdasarkan masukan dari diskusi/refleksi ini dapat dirancang kembali pembelajaran berikutnya. Pada prinsipnya, semua orang yang terlibat dalam kegiatan $L S$ harus memperoleh lessont lent, dengan demikian kita membangun komunitas belajar melalui $L S$. Dengan kata lain dalam kegiatan $L S$ guru (dosen) 
harus berani "membuka kelas" untuk diamati para observer terkait dengan proses dan aktivitas pembelajaran yang dilakukan.

Untuk mempermudah pemahaman kita mengenai tahapan $L S$ berikut ini kami gambarkan alur tahapan tersebut:

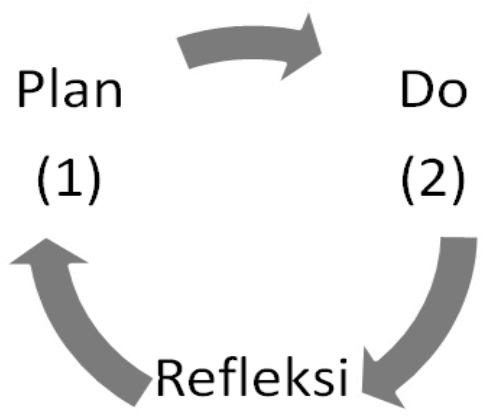

(3)

\section{Pentingnya $L S$ bagi Pembelajaran PAI}

Selama pendidikan masih ada, maka selama itu pula masalahmasalah tentang pendidikan akan selalu muncul dan orang pun tak akan henti-hentinya untuk terus membicarakan dan memperdebatkan tentang keberadaannya, mulai dari hal-hal yang bersifat fundamental-filosofis sampai dengan hal-hal yang sifatnya teknis-operasional. Sebagian besar pembicaraan tentang pendidikan terutama tertuju pada bagaimana upaya untuk menemukan cara yang terbaik guna mencapai pendidikan yang bermutu dalam rangka menciptakan sumber daya manusia yang handal, baik dalam bidang akademis, sosio-personal, maupun mental-spiritual.

Salah satu masalah atau topik pendidikan yang belakangan ini menarik untuk diperbincangkan yaitu tentang $L S$, yang muncul sebagai salah satu alternatif guna mengatasi masalah praktik pembelajaran yang selama ini dipandang kurang efektif. Seperti dimaklumi, bahwa sudah sejak lama praktik pembelajaran di 
Indonesia termasuk pembelajaran PAI pada umumnya cenderung dilakukan secara konvensional yaitu melalui teknik komunikasi oral dengan didominasi metode ceramah.

Dalam kasus pembelajaran PAI, praktik pembelajaran konvesional semacam ini lebih cenderung menekankan pada bagaimana guru mengajar (teacher-centered) dari pada bagaimana siswa belajar (student-centered), dan secara keseluruhan hasilnya dapat kita maklumi yang ternyata tidak banyak memberikan kontribusi signifikan bagi peningkatan mutu proses dan hasil pembelajaran siswa. Untuk merubah kebiasaan praktik pembelajaran dari pembelajaran konvensional ke pembelajaran yang berpusat kepada siswa memang tidak mudah, terutama di kalangan guru yang tergolong pada kelompok laggard (penolak perubahan/inovasi). Dalam kondisi seperti itu, LS tampaknya dapat dijadikan sebagai salah satu alternatif guna mendorong terjadinya perubahan dalam praktik pembelajaran PAI di Indonesia menuju ke arah yang jauh lebih efektif.

Catherine Lewis, ${ }^{6}$ berdasarkan hasil observasinya mengemukakan nilai-nilai positif implementasi $L S$, yaitu:

1. Tujuan bersama untuk jangka panjang. $L S$ didahului adanya kesepakatan dari para guru tentang tujuan bersama yang ingin ditingkatkan dalam kurun waktu jangka panjang dengan cakupan tujuan yang lebih luas, misalnya untuk materi pembelajaran PAI tentang pengembangan sikap toleransi dan empati, pengembangan akhlakul karimah, pengembangan kesalehan individual dan sosial siswa, pengembangan kemampuan akademik siswa terhadap mata pelajaran PAI yang bersifat pemahaman konsep, pengembangan pembelajaran yang menyenangkan, mengembangkan kreativitas dan kerajinan siswa dalam belajar, dan sebagainya.

'Ibid. Lihat juga Bill Cerbin \& Bryan Kopp, A Brief Introduction to College Lesson Study. Lesson Study Project, http://www.uwlax.edu/sotl/lsp/index2.htm, diakses pada 10 Januari 2009. 
2. Materi pelajaran yang penting. $L S$ memfokuskan pada materi atau bahan pelajaran yang dianggap penting dan menjadi titik lemah dalam pembelajaran siswa serta sangat sulit untuk dipelajari siswa. Untuk materi PAI misalnya tema-tema yang terkait dengan praktik fiqh seperti praktik berwudlu', sholat, haji dan lain sebagainya yang sangat penting dipahami dan dikuasai siswa terlebih dahulu.

3. Studi tentang siswa secara cermat. Fokus yang paling utama dari $L S$ adalah pengembangan dan pembelajaran yang dilakukan siswa. Misalnya, apakah siswa menunjukkan minat dan motivasinya dalam belajar PAI, bagaimana siswa bekerja dalam kelompok kecil dalam mendiskusikan sebuah tema dalam materi PAI, bagaimana siswa melakukan tugas-tugas PAI yang diberikan guru, serta hal-hal lainya yang berkaitan dengan aktivitas, partisipasi, serta kondisi dari setiap siswa dalam mengikuti proses pembelajaran PAI. Dengan demikian, pusat perhatian tidak lagi hanya tertuju pada bagaimana cara guru dalam mengajar PAI sebagaimana lazimnya dalam sebuah supervisi kelas yang dilaksanakan oleh kepala sekolah atau pengawas sekolah.

4. Observasi pembelajaran secara langsung. Observasi langsung boleh dikatakan merupakan jantungnya $L S$. Untuk menilai kegiatan pengembangan dan pembelajaran PAI yang dilaksanakan siswa tidak cukup dilakukan hanya dengan cara melihat dari Rencana Pelaksanaan Pembelajaran (Lesson Plan) atau hanya melihat dari tayangan video, namun juga harus mengamati proses pembelajaran PAI secara langsung di kelas. Dengan melakukan pengamatan langsung, data yang diperoleh tentang proses pembelajaran PAI akan jauh lebih akurat dan utuh, bahkan sampai hal-hal yang detil sekalipun dapat digali. Penggunaan rekaman bisa saja digunakan hanya sebatas pelengkap, dan bukan sebagai pengganti.

Dalam konteks pembelajaran PAI, diyakini bahwa praktek dan implementasi pola $L S$ secara berkelanjutan akan mampu 
meningkatkan profesionalisme guru-guru PAI yang pada akhirnya akan berdampak pada peningkatan kualitas pembelajaran PAI itu sendiri. Oleh karena itu, implementasi LS untuk pembelajaran PAI merupakan terobosan strategis dalam peningkatan kualitas pembelajaran PAI yang mutlak segera dijadikan sebagai tradisi peningkatan mutu pembelajaran.

\section{Implementasi $L S$ dalam Pembelajaran PAI}

Untuk dapat memulai kegiatan $L S$ dalam pembelajaran PAI maka diperlukan perubahan dari dalam diri guru PAI sehingga setidaknya memiliki sikap sebagai berikut:

1. Semangat introspeksi terhadap apa yang sudah dilakukan selama ini terhadap proses pembelajaran. Hal ini dapat dilakukan misalnya dengan mengajukan pertanyaan terhadap diri sendiri dengan pertanyaan seperti:

a. Apakah saya sudah melakukan tugas sebagai guru PAI dengan baik?

b. Apakah pembelajaran PAI yang saya lakukan telah sesuai dengan kompetensi yang diharapkan untuk dicapai oleh para siswa?

c. Apakah saya telah membuat siswa merasa jenuh dengan pembelajaran PAI saya?

d. Adakah strategi-strategi lain yang lebih baik yang bisa digunakan untuk melaksanakan pembelajaran PAI ini selain strategi yang biasa saya gunakan?

e. Apakah ada alternatif kegiatan belajar lain yang juga cocok untuk pembelajaran PAI ini?

f. Adakah media pembelajaran yang lebih baik yang dapat dipakai untuk pembelajaran PAI ini selain dari media pembelajaran yang biasa saya gunakan?

g. Mengapa siswa saya tidak termotivasi untuk mengikuti pembelajaran PAI dari saya?

h. Apakah selama ini saya telah menggunakan instrumen evaluasi PAI yang tepat? 
i. Pertanyaan-pertanyaan lain yang relevan untuk membantu guru dalam melakukan introspeksi. ${ }^{7}$

2. Serangkaian pertanyaan tersebut harus dijawab dengan jujur oleh setiap guru PAI yang ingin terlibat/dilibatkan dalam kegiatan $L S$. Jawaban terhadap pertanyaan-pertanyaan tersebut di atas tentu akan mendorong guru PAI pada proses pencarian cara untuk menyempurnakan kekurangankekurangan PBM-nya selama ini.

3. Keberanian membuka diri untuk dapat menerima saran dari orang lain untuk peningkatan kualitas diri.

4. Keberanian untuk mengakui kesalahan diri sendiri.

5. Keberanian untuk mau mengakui dan memakai ide orang lain yang baik.

6. Keberanian memberikan masukan yang jujur dan penuh penghormatan

Jika guru PAI yang terlibat dalam kegiatan LS sudah memiliki atau menyadari pentingnya sikap-sikap di atas, maka langkah selanjutnya adalah memfokuskan kegiatan $L S$ dengan cara menyepakati tema permasalahan dan pembelajaran yang akan diangkat dalam kegiatan. Kemudian kelompok $L S$ dapat membuat perencanaan pembelajaran PAI yang akan dilakukan. Perencanaan pembelajaran ini dituangkan dalam bentuk perangkat pembelajaran dan lembar instrumen observasi pengumpulan data PBM.

Penyusunan lembar observasi untuk mengumpulkan data PBM merupakan suatu elemen penting $L S$ yang didasarkan pada rencana pembelajaran yang disusun. Lembar observasi ini akan memandu pengamat untuk memperhatikan aspek-aspek khusus yang menjadi fokus kegiatan $L S$. Pengumpulan data dari hasil observasi PBM ini biasanya terkait dengan suasana kelas, ketercapaian tujuan pembelajaran, keterlaksanaan langkah-

7Suhadi, "Penyusunan Perangkat Pembelajaran dalam Kegiatan Lesson Study", Makalah yang disajikan pada Pelatihan Lesson Study untuk Guru SMP, tanggal 27 s.d. 31 Mei 2007. 
langkah pembelajaran yang telah direncanakan, hambatanhambatan yang muncul saat PBM berlangsung, antusiasme siswa, dan sebagainya.

Perangkat pembelajaran adalah sejumlah bahan, alat, media, petunjuk dan pedoman yang akan digunakan dalam proses pembelajaran atau digunakan pada tahap tindakan (do) dalam kegiatan $L S$. Karena $L S$ adalah kegiatan yang direncanakan, dilakukan, dan dinilai bersama oleh kelompok, maka perlu disadari bahwa keberhasilan dan kegagalan PBM adalah tanggung jawab semua anggota kelompok itu. Oleh karena itu, tujuan utama penyusunan perangkat pembelajaran adalah agar segala sesuatu yang telah direncanakan bersama dapat tercapai.

Adapun perangkat pembelajaran yang disusun dalam tahap perencanaan (plan) suatu kegiatan $L S$ meliputi:

1. Rencana pembelajaran yang komponen-komponennya meliputi:

a. Standar kompetensi dan kompetensi dasar, dalam hal ini kita harus memilih dari kurikulum PAI.

b. Pokok bahasan, dipilih dari kurikulum PAI.

c. Indikator, disusun sendiri oleh kelompok guru PAI dan dijabarkan dari standar kompetensi.

d. Model pembelajaran, dipilih sesuai penekanan kompetensi dan materi.

e. Skenario pembelajaran, berisi urutan aktivitas pembelajaran siswa dan mencerminkan pilihan model Pembelajaran.

f. Urutan metode pembelajaran, disesuaikan dengan aktivitas siswa dan model pembelajaran.

g. Media pembelajaran, dipilih dan diurutkan sesuai skenario pembelajaran.

h. Instrumen evaluasi meliputi ranah kognitif, afektif, dan psikomotorik

2. Lembar Kerja Siswa (LKS) yang berisi langkah-langkah kegiatan belajar siswa. LKS yang disusun dapat bersifat 
panduan tertutup yang dapat dikerjakan siswa sesuai dengan tuntunan yang ada. LKS bisa juga bersifat semi terbuka, yaitu dengan memberi peluang bagi siswa untuk mengembangkan kreativitasnya, walaupun masih ada peranan guru dalam memberikan arahan. Selain itu LKS dapat pula berupa modul pembelajaran PAI. LKS model apapun yang disusun harus mampu memberikan panduan agar siswa dapat belajar dengan benar, baik dari segi proses keilmuan maupun dalam memperoleh konsep.

3. Teaching guide (panduan guru). Dalam LS pembelajaran PAI perencanaan dibuat oleh kelompok guru PAI, namun pelaksanaannya tetap dilakukan oleh seorang guru. Agar apa yang direncanakan sesuai dengan yang dilaksanakan, maka perlu adanya pedoman/petunjuk guru. Panduan guru ini biasanya berisi bagaimana guru harus mengorganisasi siswa, mengunakan LKS, memimpin diskusi sampai bagaimana guru harus mengevaluasi.

4. Media pembelajaran. Media pembelajaran yang dipergunakan dalam proses pembelajaran PAI di dapat berupa perangkat lunak seperti: lembar transparansi, gambar, CD maupun perangkat keras seperti: OHP, LCD, VCD Player, piranti demonstrasi ataupun piranti ekperimen. Perlu digarisbawahi bahwa $L S$ melibatkan banyak orang, dalam kaitannya dengan manajemen waktu dan media pembelajaran, maka guru harus benar-benar melakukan uji waktu sebelum tampil, apalagi jika menggunakan perangkat untuk demonstrasi atau eksperimen.

5. Instrumen evaluasi, yang meliputi:

a. Evaluasi kognitif untuk melihat daya serap anak terhadap materi yang dipelajari. Dalam materi pembelajaran PAI, evaluasi jenis ini lebih ditekankan pada penguasaan konsep-konsep dasar yang prioritasnya harus dibuat secara gradual. Misalnya dimulai dari konsep-konsep tentang akidah, namun harus disampaikan dengan 
Ahmad Munjin Nasih dan Khoirul Adib, Lesson Study dalam Pembelajaran Pendidikan...

mekanisme yang simpel, mudah dipahami dan menyenangkan.

b. Evaluasi afektif untuk melihat perubahan perilaku, etika, dan nilai-nilai (value) pada siswa. Model evaluasi yang kedua ini merupakan ruh (substansi utama) evaluasi dalam pembelajaran PAI.

c. Evaluasi psikomotorik untuk mengetahui keterampilan siswa dalam melakukan pekerjaan. Evaluasi jenis ini diterapkan dalam kontek pembelajaran PAI yang menekankan pada kemampuan siswa dalam mempraktekkan amaliah-amaliah yang tergolong ibadah atau ritual baik yang wajib maupun yang sunnah. Instrumen ini disusun baik dalam bentuk instrumen test maupun non tes, seperti tes unjuk kerja, portofolio dan sebagainya.

Untuk lebih jelasnya, berikut ini akan diuraikan secara ringkas tentang tahapan dalam penyelengggaraan $L S$ dalam pembelajaran PAI.

1. Tahapan perencanaan (plan). Dalam tahap perencanaan, para guru PAI yang tergabung dalam $L S$ berkolaborasi untuk menyusun RPP yang mencerminkan pembelajaran PAI yang berpusat pada siswa. Perencanaan diawali dengan kegiatan menganalisis kebutuhan dan permasalahan yang dihadapi dalam pembelajaran, seperti tentang: kompetensi dasar, cara membelajarkan siswa, menyiasati kekurangan fasilitas dan sarana belajar, dan sebagainya. Dengan demikian dapat diketahui berbagai kondisi nyata yang akan digunakan untuk kepentingan pembelajaran. Selanjutnya, secara bersama-sama pula dicarikan solusi untuk memecahkan segala permasalahan yang ditemukan. Kesimpulan dari hasil analisis kebutuhan dan permasalahan menjadi bagian yang harus dipertimbangkan dalam penyusunan RPP PAI, sehingga RPP menjadi sebuah perencanaan yang benar-benar sangat matang, yang di dalamnya sanggup mengantisipasi segala 
kemungkinan yang akan terjadi selama pelaksanaan pembelajaran PAI berlangsung, baik pada tahap awal, tahap inti sampai dengan tahap akhir pembelajaran.

2. Tahapan pelaksanaan (do). Pada tahapan ini terdapat dua kegiatan utama, yaitu: (1) kegiatan pelaksanaan pembelajaran PAI yang dilakukan oleh salah seorang guru PAI yang disepakati atau atas permintaan sendiri untuk mempraktikkan RPP PAI yang telah disusun bersama, dan (2) kegiatan pengamatan atau observasi yang dilakukan oleh anggota atau komunitas $L S$ yang lainnya, seperti guru PAI maupun guru bidang studi lainnya, kepala sekolah, atau pengawas sekolah, atau undangan lainnya yang bertindak sebagai observer. Beberapa hal yang harus diperhatikan dalam tahapan pelaksanaan, di antaranya adalah:

a. Guru PAI melaksanakan pembelajaran sesuai dengan RPP PAI yang telah disusun bersama.

b. Siswa diupayakan menjalani proses pembelajaran PAI dalam setting yang wajar dan natural, tidak dalam keadaan under pressure yang disebabkan adanya program $L S$.

c. Selama kegiatan pembelajaran PAI berlangsung, pengamat tidak diperbolehkan mengganggu jalannya kegiatan pembelajaran dan mengganggu konsentrasi guru maupun siswa.

d. Pengamat melakukan pengamatan secara teliti terhadap interaksi siswa-siswa, siswa-bahan ajar, siswa-guru, siswalingkungan lainnya, dengan menggunakan instrumen pengamatan yang telah disiapkan sebelumnya dan disusun bersama-sama.

e. Pengamat harus dapat belajar dari pembelajaran PAI yang berlangsung dan bukan untuk mengevalusi guru.

f. Pengamat dapat melakukan perekaman melalui video camera atau photo digital untuk keperluan dokumentasi dan bahan analisis lebih lanjut dan kegiatan perekaman tidak mengganggu jalannya proses pembelajaran. 
g. Pengamat melakukan pencatatan tentang perilaku belajar siswa selama pembelajaran PAI berlangsung, misalnya tentang komentar atau diskusi siswa dan diusahakan dapat mencantumkan nama siswa yang bersangkutan, terjadinya proses konstruksi pemahaman siswa melalui aktivitas belajar siswa. Catatan dibuat berdasarkan pedoman dan urutan pengalaman belajar siswa yang tercantum dalam RPP.

3. Tahapan refleksi (see). Ini merupakan tahapan yang sangat penting karena upaya perbaikan proses pembelajaran PAI selanjutnya akan bergantung dari ketajaman analisis para perserta berdasarkan pengamatan terhadap pelaksanaan pembelajaran PAI yang telah dilaksanakan. Kegiatan refleksi dilakukan dalam bentuk diskusi yang diikuti seluruh peserta $L S$ yang dipandu oleh kepala sekolah atau peserta lainnya yang ditunjuk. Diskusi dimulai dari penyampaian kesan-kesan guru yang telah mempraktikkan pembelajaran, dengan menyampaikan komentar atau kesan umum maupun kesan khusus atas proses pembelajaran PAI yang dilakukannya, misalnya mengenai kesulitan dan permasalahan yang dirasakan dalam menjalankan RPP PAI yang telah disusun.

Selanjutnya, semua pengamat menyampaikan tanggapan atau saran secara bijak terhadap proses pembelajaran PAI yang telah dilaksanakan, bukan terhadap guru yang bersangkutan. Dalam menyampaikan saran-saranya, pengamat harus didukung oleh bukti-bukti yang diperoleh dari hasil pengamatan, tidak berdasarkan opini belaka. Berbagai pembicaraan yang berkembang dalam diskusi dapat dijadikan umpan balik bagi seluruh peserta untuk kepentingan perbaikan atau peningkatan proses pembelajaran PAI. Oleh karena itu, sebaiknya seluruh peserta pun memiliki catatancatatan pembicaraan yang berlangsung dalam diskusi.

4. Tahapan tindak lanjut (act). Dari hasil refleksi dapat diperoleh sejumlah pengetahuan baru, rekomendasi-rekomendasi 
maupun keputusan-keputusan penting guna perbaikan dan peningkatan proses pembelajaran PAI, baik pada tataran individual, maupun manajerial. Pada tataran individual, berbagai temuan dan masukan berharga yang disampaikan pada saat diskusi dalam tahapan refleksi (see) tentunya menjadi modal bagi para guru PAI, baik yang bertindak sebagai pengajar maupun observer untuk mengembangkan proses pembelajaran PAI ke arah lebih baik. Pada tataran manajerial, dengan pelibatan langsung kepala sekolah sebagai peserta LS, tentunya kepala sekolah akan memperoleh sejumlah masukan yang berharga bagi kepentingan pengembangan manajemen pendidikan di sekolahnya secara keseluruhan. Kalau selama ini kepala sekolah banyak disibukkan dengan hal-hal di luar pendidikan, dengan keterlibatannya secara langsung dalam $L S$, maka dia akan lebih dapat memahami apa yang sesungguhnya dialami oleh guru dan siswanya dalam proses pembelajaran, sehingga diharapkan kepala sekolah dapat semakin lebih fokus lagi untuk mewujudkan dirinya sebagai pemimpin pendidikan di sekolah.

\section{Catatan Akhir}

Berdasarkan uraian di atas dapat diambil kesimpulan sebagai berikut:

1. Dalam konteks pembelajaran PAI, $L S$ merupakan salah satu model pembinaan profesi pendidik atau guru PAI melalui pengkajian pembelajaran PAI secara kolaboratif dan berkelanjutan berlandaskan pada prinsip-prinsip kolegalitas dan mutual learning untuk membangun komunitas belajar yang dilaksanakan berdasarkan tahapan-tahapan secara siklik, yang meliputi: (a) tahapan perencanaan (plan); (b) pelaksanaan (do); (c) refleksi (see); dan (d) tindak lanjut (act).

2. Substansi tujuan implementasi $L S$ dalam pembelajaran PAI adalah untuk memperoleh pemahaman yang lebih baik 
tentang bagaimana siswa seharusnya belajar PAI dan guru mengajar materi PAI sehingga terjadi peningkatan kualitas pembelajaran PAI secara sistematis melalui inkuiri kolaboratif dalam setting pembelajaran PAI yang produktif, aktif, inovatif, kreatif, efektif, dan menyenangkan (PAIKEM). Dampak sampingannya ialah diperolehnya hasilhasil positif tertentu yang bermanfaat bagi para guru lainnya dalam melaksanakan pembelajaran di samping akan terbangun sebuah pengetahuan pedagogis, dimana seorang guru PAI dapat menimba pengetahuan dari guru lainnya. Adapun ciri-ciri substansi dari $L S$ yaitu adanya tujuan bersama untuk jangka panjang; materi pelajaran yang penting; studi tentang siswa secara cermat; dan observasi pembelajaran secara langsung di kelas nyata.

3. Dalam pembelajaran PAI, LS memberikan banyak manfaat bagi para guru PAI, antara lain, guru PAI dapat mendokumentasikan kemajuan kinerjanya dalam pembelajaran PAI, dapat memperoleh umpan balik dari anggota/komunitas lainnya, dan dapat mempublikasikan dan mendiseminasikan hasil akhir dari LS yang dipraktekkan sehingga secara langsung maupun tidak, akan menjadi support bagi guru-guru PAI yang lain untuk menjadikan $L S$ sebagai pijakan tradisi mutu.

\section{Daftar Pustaka}

Akhmad Sudradat, "Lesson Study untuk Meningkatkan Proses dan Hasil Pembelajaran“, Makalah disajikan pada 22 Februari 2008 pada Seminar tentang Kurikulum dan Pembelajaran.

Bill Cerbin \& Bryan Kopp, "A Brief Introduction to College Lesson Study, Lesson Study Project." http://www.uwlax.edu/sotl/lsp/index2.htm, diakses pada 10 Januari 2009. 
Catherine Lewis, "Does Lesson Study Have a Future in the United States?” $\quad$ http://www.sowi-online.de/journal/2004$1 /$ lesson lewis.htm, diakses pada 2 Januari 2009.

Lilik Nur Khalidah, "Model Internalisasi Nilai-nilai Moral Melalui Pendekatan Pemecahan Masalah dengan Kemandirian Aktif Mahasiswa pada Mata Kuliah Pengembangan Kepribadian PAI", Jurnal IPS dan Pengajarannya (2004).

Nurhadi, Pembelajaran Kontekstual dan Penerapannya dalam KBK (Malang: UM Press, 2004).

Pusat Kurikulum Depdiknas, Standar Kompentensi Mata Pelajaran Agama Islam Sekolah Dasar dan Madrasah Ibtidaiyyah (Jakarta: Depdiknas, 2004).

Suhadi, Penyusunan Perangkat Pembelajaran dalam Kegiatan Lesson Study, 2007. 